Police-Community Relations in a Majority-Black City

Ronald Weitzer

Steven A. Tuch

George Washington University, Washington, DC

Wesley G. Skogan

Northwestern University, Evanston, Illinois

\begin{abstract}
Minority racial and ethnic groups often view themselves as targets of abusive treatment at the hands of the police. Although racial variation in public assessments of the police in the United States has been amply documented in past research, less research has explored the sources of these differences at the intersection of demographic, interactional, and ecological levels. This article examines the role of each factor in shaping citizens' perceptions of police misconduct, racial differences in these perceptions, and the reasons underlying them. The locus of the study is also important. Most research on police-community relations has been conducted in cities whose populations and police departments are majority White in composition, despite the growing number of minority-White cities. The present study draws on data from residents of a majority-Black city with a majority-Black police department: Washington, DC. The findings contribute to our understanding of policing in such underresearched cities.
\end{abstract}

Keywords: police misconduct; race; public opinion

$\mathrm{T}$ The earliest American studies of race and policing focused on cities with majority-White police departments because that was all that existed at the time (e.g., Bayley and Mendelsohn 1969; Hahn 1971; Jacob 1971). Racial composition was therefore taken as a given in the early literature. But two multicity analyses were suggestive of the possible importance of a police department's racial complexion. A study of 14 cities in 1968 found that Black residents of cities with higher numbers of Black police officers held somewhat more positive views of the local police department than did

\footnotetext{
Authors' Note: Correspondence concerning this article should be addressed to Ronald Weitzer, Sociology Department, George Washington University, Washington, DC 20052; e-mail: weitzer@gwu.edu.
} 
Black residents of cities with low numbers of Black police officers (Decker and Smith 1980), and a 1975 survey of 13 cities found that the difference between White and Black attitudes toward the local police department was less marked where Black representation on the force was higher (Skogan 1979). Both samples were confined, however, to majority-White cities with majority-White police departments. Today, there are several majority-Black and majority-Hispanic cities in America, yet research on these two contexts is too sparse to draw any firm conclusions regarding the effects of racial composition on residents' views of the police (Frank et al. 1996; Howell, Perry, and Vile 2004; Murty, Roebuck, and Smith 1990; Weitzer 2000b; Welch et al. 2001). The majority of the public view the diversification of a police department positively (Weitzer and Tuch 2006), but the effects of diversification remain opaque.

The present study contributes to this literature by examining police misconduct in one majority-Black city. We examine the extent to which members of the public view selected types of misconduct as problems in their residential neighborhoods, as well as the factors shaping such perceptions. Public perceptions of police misconduct can be just as important as actual misconduct. Citizens' beliefs and expectations can affect their demeanor in encounters with police officers, their compliance with officer demands, and their willingness to assist the police by reporting crimes and serving as witnesses, and it can affect larger political and racial tensions in a city and the very legitimacy of the local police department. In other words, it is in the interest of every police department to not only reduce officer misconduct but to also be perceived as doing so, because this makes police work less contentious and more effective. Citizen satisfaction with the police can pay dividends in facilitating police crime control efforts, and it can enhance the general legitimacy of a department.

\section{Theoretical Background}

Years ago, Lawrence Sherman (1983) hypothesized,

A department with more Black officers behaves differently from a department with fewer Black officers. As Blacks comprise a larger portion of a police department, they may become less isolated and more influential in shaping the values and culture of the entire police department. (P. 221)

He implied that this would result in better treatment of the inhabitants of such cities, but it might also have distinct effects on different racial groups. 
Relevant to assessing the efficacy of this argument is the group position thesis (Blumer 1958), which emphasizes the role of intergroup relations in influencing individual perceptions and behavior: Dominant-group attitudes toward other racial groups are shaped by a sense of superiority over racial others and by a desire to defend dominant-group interests against threats, whether real or perceived. The subordinate group, however, is motivated by a sense of unfair and exclusionary treatment at the hands of the dominant group and by a desire to secure a larger share of scarce resources. Extending the thesis to group relations with institutions such as the police, individual orientations are arguably influenced by one's racial group and its general relations with the police (Weitzer and Tuch 2006:8-16). At the interactional level, citizens may interpret police behavior in terms of "the [White] officer's own ethnic group's superordination" (Sykes and Clark 1975:590). In other words, minority individuals may construe their encounters with police less in terms of the immediate circumstances and more in terms of their group's societal position. Similarly, at the symbolic level, they may view the police as a "visible sign of majority domination" (Bayley and Mendelsohn 1969:195).

The thesis would predict that in cities where the formerly subordinate racial group gains political power and control over the police department and where the formerly dominant racial group experiences diminished power, "the racial polarization we normally observe in evaluations of the police should disappear or reverse in majority Black settings" (Howell et al. 2004:50). In other words, the group position thesis would predict that when racial groups trade places in a particular city, their traditional orientation to the local police may be inverted, with Blacks being more inclined toward favorable views of the police and with Whites being less favorably disposed (Howell et al. 2004). If a group's position in the racial hierarchy shapes its orientation to the police, then changes in the relative positions of racial groups may lead to changes in the way that they relate to the police (Weitzer and Tuch 2006:8-14).

The present study examines one city-Washington, DC-where both the population and the police department are majority Black in composition. Previous research on this city is limited to an in-depth study of three neighborhoods (Weitzer 1999, 2000a, 2000b). Our study builds on this prior work in the context of the city as a whole. We cannot directly test the proposition that racial composition influences police-community relations - that would require systematic, comparative analysis of several carefully matched cities - but our research does add to the emerging literature on cities where non-Whites are the majority population and so control local 
government and the police department. Such cities are important theoretically because they depart from the traditional model where Whites control the levers of power.

\section{Explaining Citizen Perceptions of the Police}

\section{Individual Demographic Characteristics}

Research on the factors that shape citizens' attitudes toward the police usually begins with personal characteristics. The most important of these measures reflect fundamental cleavages in American society and so distinguish between those groups that generally have a stake in the established order and those that do not. Empirically and politically, race is the most important fault line along which Americans divide over policing, and three decades of research have documented racial and ethnic differences in assessments of the police and in patterns of police-citizen interactions. Blacks and Hispanics are more likely than Whites to believe that the police frequently engage in misconduct, and when compared to Whites, minority groups tend to view instances of officer misconduct as being more serious and disturbing (Weitzer 2002), partly because the victims are disproportionately minority group members.

Age is another consistent predictor of police perception. Compared to older-age groups, young people have greater contact with police officers, report more personal experience with mistreatment by officers, and hold more critical views of the police (Hurst, Frank, and Browning 2000; Leiber, Nalla, and Farnworth 1998). Gender is often insignificant by itself, but when examined in combination with age and race, it gains explanatory power. In the few studies that contain interactions of age, race, and gender, young Black men stand out. They are significantly more likely than older Black males, young White males, and young Black females to view the police negatively and to report having had bad encounters with officers (Weitzer and Tuch 2002, 2006). A parallel pattern has been found for young Hispanic males, at least on some policing issues (Skogan 2005; Weitzer and Tuch 2006).

The role of social class is less clear. In some studies, class has no effect on attitudes toward the police; in other studies, it is significant for Blacks or Hispanics but not for Whites; and in those studies where it is a predictor, the results are mixed. Regarding the last point, some studies have found that middle-class Blacks are more satisfied with the police than disadvantaged Blacks are, whereas other studies have found the opposite (e.g., Alpert and 
Dunham 1988; Hagan and Albonetti 1982; Smith, Graham, and Adams 1991; Weitzer and Tuch 1999, 2002; Wortley, Hagan, and Macmillan 1997). One explanation for these discrepant findings is issue specificity: A policing issue may have differential salience among members of various social classes. To gain clarity on the conditions under which social class shapes police-citizen relations, it is important to include this variable in explanatory models.

\section{Neighborhood Crime, Disorder, and Policing}

Recent research suggests that in addition to demographic factors, neighborhood context is important in explaining police-citizen relations. Neighborhoods differ in the amount and quality of policing that they receive (Klinger 1997; Smith 1986), and these differing police practices likely shape, at least to some extent, residents' perceptions of the police.

The opportunity structure is an important variable: Opportunities for police misconduct are far greater in communities with high rates of crime and social disorder than they are elsewhere. The sheer number of officers patrolling these neighborhoods is typically greater than that in quieter areas, whose residents rarely see the police, thus increasing the frequency of police-citizen contacts and the potential for acrimonious encounters. Some high-crime neighborhoods experience saturation patrolling, but even the more routine proactive police practices in high-crime and disorderly areas may amplify friction between officers and residents-with a cumulative adverse effect on residents' opinions of the police. In addition, the street crime typical of some of these communities offers far more opportunities for police corruption and other abuses of power-namely, robbing drug dealers, planting evidence, and otherwise mistreating residents (Mollen Commission 1994).

That police typify certain neighborhoods as being troublesome leads officers to stereotype residents as those who are uncooperative, hostile, or crime prone- thereby resulting in their tendency to approach residents with greater suspicion, to behave more aggressively, and to act more punitively than they do in other kinds of neighborhoods (Smith 1986). Studies based on police records and field observations indicate that police officers' verbal and physical abuse, unjustified street stops, and corruption are more prevalent in disadvantaged and high-crime areas (Fagan and Davies 2000; Kane 2002; Mastrofski et al. 2002; Smith 1986; Terrill and Reisig 2003).

In addition to greater opportunities for police officers' mistreatment of people in such communities, the residents typically lack the capacity to 
constrain such behavior by holding officers accountable. The same conditions that foster crime in a neighborhood may also loosen some of the bounds controlling police conduct. In other words, neighborhood disorganization may be associated not only with residents' incapacity to organize against crime and disorder - a key tenet of social disorganization theory-but also with their powerlessness in the face of abusive police practices (Kane 2002; Kubrin and Weitzer 2003). In socially disorganized neighborhoods, residents lack the capacity to mobilize against police mistreatment, whereas residents of more affluent communities have connections to local elites who can be mobilized to hold officers accountable (Weitzer 1999, 2000a).

Neighborhood crime is also salient. If residents' dissatisfaction with the police in disadvantaged communities is in part a function of greater opportunities for and fewer constraints on police misconduct and if these opportunities and constraints are related to the level of crime and disorganization in those communities, then it is reasonable to expect that citizens' opinions of the police will be lower in neighborhoods with high levels of street crime or in places where residents perceive a great deal of crime (Brown and Benedict 2002). Communities whose residents believe that crime is a serious problem in their neighborhoods are more likely than residents of other areas to be critical of the police (Huebner, Schafer, and Bynum 2004; Jesilow, Meyer, and Namazzi 1995; RAND 2005; Weitzer and Tuch 2006), and the same is true for those who report that a violent crime occurred in the neighborhood in the past year (Weitzer and Tuch 2002). The same pattern is evident when the measure is the official crime rate: Areas high in violent crime register lower levels of approval of the police (Murty et al. 1990; Reisig and Parks 2000; Sampson and Bartusch 1998; Schafer, Huebner, and Bynum 2003). Interestingly, one study found that in shaping attitudes toward the police, residents' perceptions of neighborhood crime are more important than official crime rates (Huebner et al. 2004). As such, this leads to our first hypothesis:

Hypothesis 1: Police misconduct will be viewed as a larger problem in communities whose residents also perceive crime as being high in the locale.

If this hypothesis is supported for the general population, we examine whether residence in such communities differentially affects Blacks' and Whites' views of police misconduct.

Neighborhood disorder may have a similar effect. Social disorder includes public drinking, panhandling, loitering, vandalism, truancy, and unsupervised youth. Neighborhood social disorder is substantially correlated 
with street crime (Sampson and Raudenbush 1999; Skogan 1990), and in popular perceptions, the two are closely related. Research indicates that disorder undermines residents' confidence in the police: Citizens appear to "hold the police at least partially responsible for the disorder" in their communities (Cao, Frank, and Cullen 1996:13; cf. MacDonald et al. 2007; Reisig and Parks 2004; Xu Fiedler, and Flaming 2005). Pressure from the public to "do something" about disorder can be interpreted as pressure to "do anything," and the constitutional complexity of responding aggressively to problems such as loitering and panhandling creates further opportunities for police misconduct. Disorder may therefore be a part of the ecological context conducive to police misconduct in disadvantaged neighborhoods. The argument is that neighborhood disorder, like street crime, creates greater temptation for abuse of power, with the result being that high-disorder neighborhoods will have worse relations with the police, when compared to other neighborhoods:

Hypothesis 2: Police misconduct will be viewed as a larger problem by residents who perceive their neighborhood as having a high level of social disorder.

If this hypothesis is supported for the general population, we examine whether residence in such communities differentially affects Blacks' and Whites' views of police misconduct.

\section{Community Policing}

Police conduct on the street may also be related to the prevailing style of policing employed in the community. Residents in areas where community policing is practiced might be expected to have better relations with the police when compared to those in areas policed in a traditionally disengaged and reactive fashion. In principle, community policing encourages residents and officers to work together to identify and resolve local problems. Such collaboration may foster improved relations between the parties, increase public understanding of local policing strategies, and perhaps reduce the incidence of police abuse of citizens. What remains an open question is whether police-community relations are indeed better in such neighborhoods than in areas where traditional policing predominates (Weitzer 2005). Studies of some community policing programs have found that they do not significantly improve residents' relations with the police, either because they are defined as being intrusive and unwelcome or because officers are seen as lacking a real commitment to community engagement 
(Grinc 1994; Williams 1997). Other studies, however, document positive outcomes associated with foot-and-bike patrols, community meetings, and other types of community policing (Reisig and Parks 2004; Skogan 2006b; Weitzer and Tuch 2006). This literature is inconclusive, but the thesis lying behind community policing predicts that it should make a difference in public assessments of the quality of police service. Indeed, it was the need to establish a legitimacy in minority and immigrant communities that impelled many police departments to adopt community policing in the first place (Skogan 2006b). In the present study, public perception of community policing is operationalized by citizens' beliefs that officers are working with residents to deal with neighborhood problems and are responsive to residents' concerns:

Hypothesis 3: Police misconduct will be seen as a lesser problem in neighborhoods where police are viewed as implementing an effective community policing program.

If this hypothesis is supported for the general population, we examine whether Blacks and Whites are differentially affected by residence in such neighborhoods.

\section{Police-Citizen Encounters}

Citizens' encounters with police officers may also influence their larger attitudes toward the police. Some early studies reported that citizens' prior contacts with officers influenced their general views of the police (Dean 1980; Scaglion and Condon 1980), and more recent research has indicated that the quality of treatment that people receive during encounters makes a difference. People who feel that they have been treated courteously and fairly, that they have been addressed without racial animus, and that they have been informed of both their rights and the reasons behind police actions are more likely to be satisfied-even when the outcome is not favorable toward them as citizens, such as receiving a traffic ticket or getting arrested (Skogan 2005; Stone and Pettigrew 2000; Tyler and Huo 2002). The kind of treatment that people receive from police officers is important regardless of one's racial background (Tyler and Huo 2002), yet race continues to play a role: Blacks are more likely than Whites to report that they have received unfair or disrespectful treatment from officers, thus contributing to their more critical views of the police (Engel 2005; Skogan 2005; Tyler and Huo 2002; Weitzer and Tuch 2006). Indeed, some demographic 
correlates of attitudes toward the police, such as race and age, may indirectly reflect the effects of experiential factors that are highly differentiated by race and age.

The type of contact also makes a difference. The literature distinguishes between positive and negative contacts and between citizen-initiated (or voluntary) contacts and police-initiated (involuntary) contacts (Decker 1981). Findings are mixed regarding the consequences of different kinds of contacts. Some studies have found that citizen satisfaction is higher when the encounter is citizen initiated (Cheurprakobkit 2000; Jesilow et al. 1995; Reisig and Parks 2000). This finding is consistent with the assumption that police-initiated contacts are not only unsought but more often inquisitorial or adversarial from the outset. Other research, however, has found that positively rated encounters (irrespective of who initiates them) do nothing to enhance overall satisfaction with the police (Dean 1980; Reisig and Parks 2000; Schafer et al. 2003). That is, police get little or no credit for good performance, whereas poor performance increases negative assessmentshence, a striking asymmetry in the impact of encounters (Skogan 2006a). This dynamic is consistent with a broader negativity bias that is well documented in the psychological literature: Negative experiences have greater cognitive and emotional salience and longevity than do positive ones (Baumeister et al. 2001; Rosin and Royzman 2001).

In short, there is considerable evidence that police-initiated contacts negatively affect citizens' opinions of the police, and we expect that this will remain true in a city with a majority-Black police department: The voluntary or involuntary nature of the contact will determine citizens' reactions irrespective of the police department's racial composition:

Hypothesis 4: Police-initiated contacts will heighten perceptions of police misconduct among both Blacks and Whites.

The consequences of citizen-initiated contacts, however, are somewhat less clear from the literature. As such, we predict the following:

Hypothesis 5: Citizen-initiated contacts will not affect perceptions of police misconduct among either Blacks or Whites.

It is important to recognize that there are qualitatively different types of citizen-initiated contact as well as different types of police-initiated contact, though most of the literature fails to draw these distinctions. Each subtype deserves to be examined in its own right because it may involve citizen 
experiences different from those of other subtypes. Consequently, we separately examine the impact of two types of citizen-initiated contact (crime related and noncrime related) and two types of police-initiated contact (vehicle and pedestrian stops).

The present study analyzes popular assessments of police misconduct in several ways: through a comparative analysis of the views of Blacks and Whites; through the interaction effects of race, age, and gender on perceptions; through the impact of multiple types of police-citizen contacts; and through the role of citizen-reported neighborhood conditions in shaping assessments of police misconduct.

\section{The Setting}

As indicated above, virtually all city-level studies of police-citizen relations in the United States have examined only one type of context: cities with majority-White police departments and/or majority-White populations. Very little is known about other contexts. We know that minority opinion of the police is less positive than White opinion in majority-White cities and at the national level, but are minorities equally critical of the police in cities with majority-Black or majority-Hispanic populations and police departments? Unfortunately, studies of these types of cities are so rare that the question cannot be answered at present (Frank et al. 1996; Howell et al. 2004; Murty et al. 1990; Weitzer 1999, 2000a, 2000b; Welch et al. 2001).

Washington, DC, presents an ideal case for examining this issue. The city's Metropolitan Police Department (MPD) is majority Black, and the racial composition of the department roughly matches the racial composition of the city. At the time of the study, African Americans composed 58 percent of the city's population and 66 percent of the MPD (Bureau of Justice Statistics 2004). The MPD is also unique in having the highest number of Black officers in supervisory positions of any large majorityBlack city in the country (53 percent in 1992 - and probably higher by the time that our surveys were administered at the end of the decade; Walker and Turner 1992). Moreover, at the time of the study and for many years preceding it, Washington's mayors and police chiefs were African American. The impact, if any, of such key elites on police practices or police-citizen relations is unknown, but it is possible that they have a positive symbolic effect on the department's image and/or some diffuse effect on aggregate police practices. A recent study of 170 cities found that the 
presence of a Black mayor reduced police killings, after controlling for other factors (Jacobs and O'Brien 1998).

The MPD has had its share of problems. In recent years, these have included inadequate resources, poor training, and mismanagement (Human Rights Watch 1998; Kappeler, Sluder, and Alpert 1998). In a 1998 exposé, the Washington Post reported that during the 1990s, MPD officers shot and killed more people per capita than any other large American police force did. Subsequently, the MPD reformed its use-of-force procedures, and fatal police shootings substantially declined (Washington Post 2000, 2001).

Traditional reactive policing is the norm in Washington, DC. Community policing is less institutionalized than it is in cities such as Chicago (Illinois), San Diego (California), and Savannah (Georgia), but Washington does have one longstanding community policing mechanism: It holds regular police-community meetings, under the rubric of Citizen Advisory Councils, in each of the city's seven police districts. These meetings are open to the public and are held every month; they have existed in one form or other since 1968. Around the time of the present survey, similar neighborhood-based meetings were held in each of 83 newly created beats-called patrol service areas. At the time of our survey, 58 percent of respondents reported that they were aware of a meeting in their neighborhood on crime issues, a view shared equally by Whites and Blacks.

The MPD also conducts foot-and-bike patrols in selected neighborhoods and periodically sponsors other community-oriented programs (house-tohouse meet-and-greet contacts, programs for schoolchildren). A 1998 survey found that 40 percent of city residents had observed (directly or via media reporting) police officers attending community meetings; 39 percent had seen foot-and-bike patrols; 20 percent had seen officers working with residents to address problems; and 15 percent had seen police officers participating in youth programs (Bureau of Justice Statistics 1999). However, the survey also found that only 3 out of 10 city residents believed that the police were "doing anything new to cooperate with the community" (p. 29).

\section{Method}

The data for this article were collected in two citywide surveys of adult residents (18 years of age or older). The surveys were conducted by Macro International, a public opinion research firm in Burlington, Vermont, under the supervision of the third author. The first survey was conducted between June 1998 and August 1998 and the second between December 1999 and 
January 2000. Both surveys addressed respondents' attitudes toward and their reported contacts with the police, as well as their perceptions of and experiences in their neighborhoods and elsewhere in Washington. Question wording for all variables analyzed in this article were identical in the two surveys, which are combined here to increase the total sample size. Because there were no publicized incidents of serious police misconduct in the city during the 1.5-year period between the two surveys nor any other events that might significantly influence public opinion of the police, there is no reason to suspect any confounding effect of survey year. Nonetheless, we include in our model a term for year of interview.

\section{Sampling}

Both surveys were conducted using random-digit-dial computer-assisted telephone interviews. ${ }^{1}$ This sampling frame consisted of hundred-series, or banks, of numbers in which the first two digits of the last four numbers are common; these banks constituted the sampling frame. Each sampled number was screened for household eligibility to verify that the number reached was the intended number, that the call connected to a private residence located in the city, and that someone 18 years of age or older lived there. If any of these conditions was not met, the household was deemed ineligible, and the interview was terminated. The interviewer completed a brief household roster to randomly select an adult respondent from those who were eligible. Response rates were 60 percent for the 1998 survey ( $n$ $=2,216)$ and 48 percent for the 1999 survey $(n=2,420)$ for a total of 4,636 respondents: 2,640 African Americans, 1,495 non-Hispanic Whites, 176 Hispanics, and 185 others (140 respondents did not identify their race). Because Hispanics are so few in number in our sample and the other category is undifferentiated, the analyses reported below are based on data for Whites and African Americans only. After further eliminating cases with missing data on any of the study variables (see below), 2,731 respondents1,816 African Americans and 915 Whites-remain for analysis. ${ }^{2}$

\section{Dependent Variable}

Perceived police misconduct is measured by responses to questions asking "how big a problem" selected issues are in the respondent's neighborhood: police officers "stopping too many people on the streets without good reason," "being too tough on people they stop," and "being verbally or physically abusive to people."3 These items reflect some of the standard 
types of police misconduct toward citizens. Respondents were asked whether each type of behavior was a big problem, some problem, or no problem in their neighborhood. Responses were scored so that higher values reflect more negative respondent perceptions of the police who are serving their neighborhoods. ${ }^{4}$

A misconduct scale based on respondents who expressed an opinion on every question had high internal consistency: It was strongly singlefactored (with all factor loadings above .85 and with an eigenvalue of 2.213); the average interitem correlation was .62; and it had an alpha reliability of .83. However, to represent the views of as many respondents as possible, we created an index for those who replied to two items, as well as to all three, by averaging each respondent's responses. This was appropriate because responses to all three questions had approximately the same means and standard deviations. This procedure still excluded 15 percent of all respondents.

\section{Independent Variables}

Several independent variables were included in the analysis. Race was divided into White (coded 1) and African American (coded 0). Education was measured as years of schooling completed, ranging from none (coded 0 ) to $\mathrm{PhD}$ (coded 18). Young respondents (under the age of 30) and older respondents (60 and older) were differentiated from those aged 30 to 59, who were the omitted reference category in the multivariate analyses. Males (coded 1) were distinguished from females (coded 0), married (coded 1) from unmarried (coded 0), and those having children living at home (coded 1) from those who did not (coded 0). The year that the survey was conducted is another variable: 1998 (coded 1), 1999 (coded 0).

Survey instruments are not well suited to measuring objective neighborhood conditions, but they do permit documentation of the perceived extent of neighborhood crime, disorder, and community policing. The literature indicates that perceived conditions are important ingredients in residents' assessments and that perceived and objective neighborhood conditions both shape residents' attitudes toward the police (Jesilow et al. 1995; RAND 2005; Reisig and Parks 2000; Sampson and Bartusch 1998; Weitzer and Tuch 2006). Indeed, what arguably matters most is how residents view their neighborhoods, given that reality is filtered through these perceptions. As one study found, "citizens' perceptual views of their neighborhood [including amount of crime] were often more important than actual neighborhood conditions" in explaining views of the police (Huebner et al. 2004:132). ${ }^{5}$ 
Respondents' reports of the extent of neighborhood crime problems were combined to create a six-item index reflecting questions on shootings and gang violence, drug dealing, vandalism, stolen cars, breaking and entering, and robberies in the neighborhood (alpha $=.82$ ). A second index, measuring the extent of neighborhood disorder, included responses to questions concerning public drinking, prostitution, "groups of people hanging out" on the streets, cars running stop signs and red lights, and panhandlers "really giving people a hard time" (alpha $=.72)$. In both instances, respondents were asked whether each issue was a big problem, some problem, or no problem in their neighborhood. The scales were scored so that higher values reflect greater perceived crime and disorder; as such, both indices were standardized. ${ }^{6}$

The perception that there was effective community policing in the neighborhood was measured by responses to questions asking about police responsiveness to community concerns and how good a job police are doing in working with residents to solve local problems. Neither item taps beliefs about specific community policing programs; our interest focused on larger perceptions of community policing in respondents' neighborhoods-hence, the use of these generic measures. Police were rated on 4-point response categories, ranging from very responsive to very unresponsive and from very good job to very poor job working with neighborhood residents. Higher scores on the resulting scale reflect a perception of effective community policing $($ alpha $=.74)$. The community policing index was also standardized.

Citizen contacts with officers were distinguished by those that were police initiated and those that were citizen initiated. In the police-initiated category, we differentiated between police-initiated vehicle stops and police-initiated pedestrian stops. Respondents were asked if they had been stopped by an MPD officer in the past year in a car or motorcycle (policeinitiated vehicle stop) and if they had been stopped in the past year "when [they] were out walking" (police-initiated pedestrian stop). Both variables were coded 1 for yes and 0 for no. Overall, 19 percent of Washingtonians recalled being involved in a traffic stop in the past year, and 5 percent reported being stopped while walking. There was some overlap in the measures - namely, 2 percent of city residents reported being stopped while driving and while on foot.

The extent of citizen-initiated encounters with the police was assessed by responses to four screening questions concerning crime-related contacts and five concerning other, noncrime-related matters. To establish a crimerelated contact, respondents were asked whether, in the past year, they had 
reported a crime to the police, a "suspicious person who [they] thought might be connected to a crime," "suspicious noises," and "any other event that [they] thought might lead to a crime." We used a count ranging from 0 to 4 for the number of crime-related contacts initiated by respondents. Spanning all four questions, 38 percent of respondents reported contacting the police about crime in the past year. There was a moderate positive correlation (average $r=.32$ ) between reports of these various reasons for contacting police. Contacts concerning noncrime matters were measured by responses to five questions-namely, about reporting a traffic accident or a medical emergency, asking for advice or information, giving the police information, reporting "any other neighborhood concern or problem," and reporting any other problem or difficulty. We used a count ranging from 0 to 5 to represent the extent of respondents' noncrime contacts. Spanning all five questions, 44 percent of respondents recalled contacting the police. The average correlation between these five measures was .25 . One quarter of Washingtonians (26 percent) initiated both a crime-related contact and a noncrime contact with the city's police department in the previous year. ${ }^{7}$ Taken together, these measures of prior experience with the police capture a range of both negative and potentially supportive contacts.

\section{Findings}

Demographic characteristics. Blacks were about twice as likely as Whites to believe that the city's police stop too many people without good reason, that they are too tough on people whom they stop, and that they are verbally or physically abusive toward citizens (i.e., seeing each type of abuse either as a big problem or as some problem in their neighborhoods). Nearly 30 percent of Blacks hold these views, as compared to 11-15 percent of Whites. We also report results for a fourth type of misconductpolice corruption - that is not part of our multivariate analysis below because it did not load with the other types of misconduct. Corruption was defined in the survey as "police taking bribes or getting involved in the drug business in [one's] neighborhood," and it was defined as a neighborhood problem by more Blacks (27 percent) than Whites (19 percent).

In conjunction with race, age and gender matter. Young Black men (aged 18-29) were about twice as likely as their older counterparts (60 and older) to report that police in their neighborhood stop people without good reason (43 percent versus 18 percent of young and older Blacks, respectively), that they are unnecessarily tough on people (41 percent versus 19 percent), 
engage in verbal or physical abuse (34 percent versus 15 percent), and are involved in corrupt practices in one's neighborhood (30 percent versus 14 percent). Young Black men were also 2 to 3 times more likely than young White males to hold these negative views. At the same time, the percentage of young Black men perceiving each problem was similar to that of young Black women.

Are Blacks more likely than Whites to be subjected to police-initiated stops, either in vehicles or as pedestrians? Among city residents, Blacks were slightly more likely than Whites (20 percent versus 17 percent) to report being stopped while driving in Washington in the past year. These stop rates are similar to those reported for Chicago in 2001, where 21 percent of Blacks and 13 percent of Whites said that they had been stopped in the past year while driving in the city (Skogan 2005). Relatively few Washingtonians reported being involved in a pedestrian stop, but racial disparity is nevertheless evident: 7 percent of Blacks and 2 percent of Whites said that they had been stopped in the city while on foot (compared to 9 percent and 4 percent, respectively, in Chicago). When vehicle and pedestrian stops are combined, about one quarter of all African Americans in Washington reported being stopped in the past year.

Young Black men were more likely than others to report that they had been stopped by the police, both while driving and as pedestrians. ${ }^{8}$ Regarding vehicle stops, fully 43 percent of 18 - to 29 -year-old Black males (compared to 18 percent of young White males and 17 percent of older Black males) reported such a stop in the past year. Pedestrian stops are less common, but 18 percent of young Black males (4 percent of young White males, 5 percent of older Black males) reported being stopped as pedestrians. Young Black women were significantly less likely than their male counterparts to be stopped while driving ( 24 percent) or while on foot ( 8 percent), but they did not differ much from young White women (21 percent and 3 percent, respectively). Clearly, young Black males are the group most susceptible to being stopped, both in vehicles and on foot (cf. Brunson and Miller 2006). In the span of just 1 year, 61 percent of young Black males in Washington, DC, reported being stopped by the city's police either in cars or as pedestrians-and this figure is about 3 times higher than that for young White males. Although this triple-jeopardy pattern has been documented in some other studies (Weitzer and Tuch 2002, 2006), it is noteworthy that it exists in a majority-Black city with a majority-Black police force. In terms of street stops, the racial composition of a city and its police department may not substantially reduce police suspicion of young Black males. ${ }^{9}$ 
Does social class influence the probability of being stopped? Blacks with more education were hardly immune from police scrutiny: 26 percent of Blacks with a high school education or beyond, compared to 18 percent of similarly educated Whites, reported being stopped either while driving or on foot. Not only were higher-educated Blacks more likely to be stopped than similarly situated Whites, but they were also more likely to be stopped than lesser-educated Blacks: 26 percent versus 19 percent, respectively, reported stops of any kind. The comparable figures for Whites were 18 percent and 12 percent. In other words, higher class position does not insulate people from police scrutiny.

The bivariate patterns described above tell only part of the story and may or may not persist when other factors are incorporated into a multivariate model. Table 1 displays ordinary least squares regression estimates for the effects of the individual, neighborhood, and contact predictors on perceptions of police misconduct. ${ }^{10}$ One column shows the coefficients for the total sample (Whites and Blacks combined); two other columns display the coefficients separately for Whites and Blacks, as well as tests for the significance of the White-Black slope differences. ${ }^{11}$

Consistent with most previous research and net of the effects of other variables, Blacks are significantly more likely than Whites to see police misconduct as a problem in their neighborhoods (see total sample column). Based on the magnitude of standardized regression coefficients (labeled beta in the table), race was one of the most salient factors shaping views of police misbehavior. Respondents who were married and those with more education reported less concern about police misconduct in their neighborhoods. Having children living at home was another matter. Respondents with children living at home were more concerned about police misconduct in their neighborhood. These are households with additional membersparticularly, young people-who are at risk of encountering officers in their community. As shown below, this effect was almost entirely contributed by African American respondents.

Most surveys find that age is among the most reliable predictors of attitudes toward the police, with the young perennially dissatisfied. Young people are more likely to get into trouble with the police, including being stopped and arrested. When age is considered alone, it is a predictor in the current study. The sample average on the three-item police misconduct index was 1.29; among respondents 18 to 29 years old, however, the mean was 1.38 , indicating more negative perceptions of police misconduct. For respondents aged 30 to 59, the mean was 1.32; for those 60 and older, 1.21. However, these age effects disappear once the interactions among age, race, 


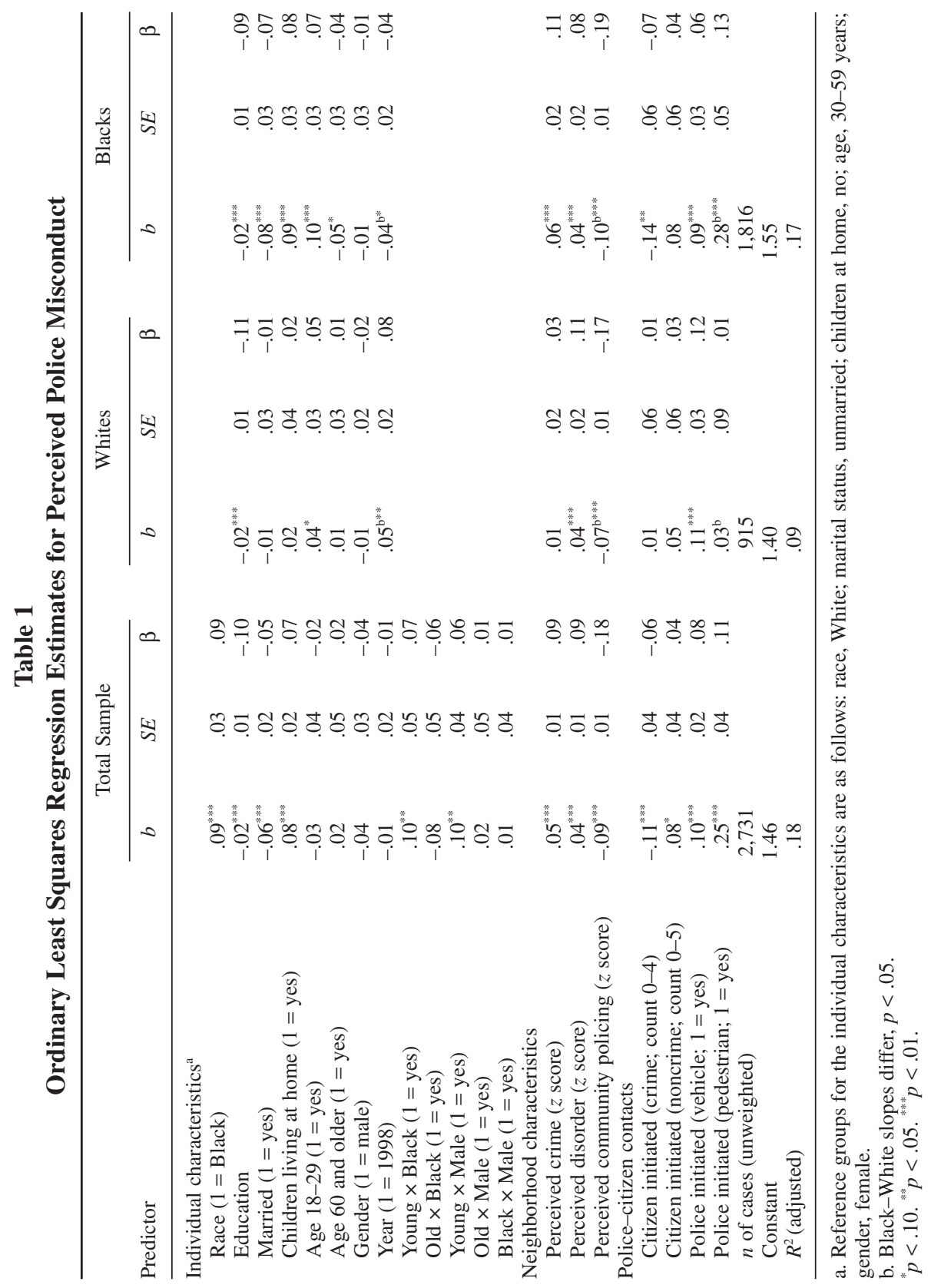


and gender are taken into account. Table 1 reports the results of including in the analysis two-way interaction terms separately identifying young and old Blacks, young and old males, and Black males. The individual factors described in the table are measured as dichotomies; as such, their unstandardized regression coefficients (labeled $b$ in the table) are comparable. The coefficients for three of the interaction terms-Young $\times$ Black, Old $\times$ Black, and Young $\times$ Male - are among the largest on the list; any main effects of being young or male disappear once membership in these key groups is taken into account. Being young and Black and young and male significantly heightens perceptions of police misconduct.

The large effects of race and race-age interactions on views of the police raise the question of whether the individual factors that shape perceptions operate in similar fashion for Blacks and Whites. Table 1 presents findings separately for Whites and Blacks and shows that individual factors do play a race-specific role. The effects in the total sample of being married and having children who live at home were all contributed by Blacks; neither factor influenced Whites' perceptions. Marriage reduced the chances of perceiving police misconduct, whereas having children at home increased perceived misconduct. Regarding the latter, it is worth noting the demography of Washington: In our survey, 42 percent of African American households reported having children living at home, compared to only 14 percent of White households. Having children at home arguably reflects Blacks' ongoing concern about their treatment by the city's police. The fact that Black youth are particularly vulnerable to having an adverse encounter with police officers, which is well known in the Black community (Brunson and Miller 2006), may explain why having children increases African Americans' belief that police misconduct is a problem in the city.

Other demographic factors have a uniform effect across the two racial groups. A relatively strong age effect-that of young people being more concerned about police misconduct-characterized Whites and Blacks. Education also has the same effect among Whites and Blacks: In both groups, those with more education were less likely to perceive any problems with misconduct in their community. This is consistent with an earlier study of Washington, which found that discontent with the police was higher in a disadvantaged Black neighborhood than in a middle-class Black neighborhood (Weitzer 1999, 2000a).

Perceived neighborhood characteristics. The selected features of our respondents' neighborhoods, as perceived by residents, had a somewhat more uniform effect on their views of police behavior there. We argued that 
neighborhood crime and disorder are linked to police misconduct through their effect on officer typification of residents, patrolling strategies, opportunities for corruption and other abuses, and residents' inability to mobilize to curb police misconduct (with this last point drawing on social disorganization theory). Empirically, the indices of perceived crime and disorder were among the strongest bivariate correlates of perceived police misconduct. In the multivariate analysis, where neighborhood crime was viewed as a problem, residents were also more likely to report problems with police misconduct. All of this effect was contributed by Blacks; among Whites there was no significant effect of perceived crime on police misconduct. Perceived neighborhood disorder, however, increased both groups' perceptions of police wrongdoing. ${ }^{12}$ The hypothesis was that pressure for more aggressive order maintenance in disorderly places can lead to policing practices that are seen by many community members as being excessive and even illegitimate. The empirical link between the two measures held in remarkably similar fashion for both Blacks and Whites.

The strongest factor in this cluster was the perceived effectiveness of neighborhood police at pursuing a community-oriented agenda. Overall and among Blacks and Whites, this was the strongest correlate of confidence in the police. Respondents who believed that police in their neighborhood were doing a good job responding to local concerns and working with neighbors to solve crime problems were less likely to believe that they were involved in misconduct. The influence of these views was somewhat stronger among Blacks than among Whites, but in both instances this view was the most important determinant of perceptions of police misconduct. In both groups, confidence that the police were community oriented was about twice as influential as the reported extent of crime and disorder. Perceptions of community policing in one's neighborhood therefore exerts a robust and strong influence on residents' opinions of the police, especially among Blacks - thus, reducing the chances that misconduct will be viewed a local problem.

Police-citizen contacts. Finally, recent encounters with officers shaped popular views of misconduct, contingent on the nature of the contact and the race of those involved. Responding quickly when called and taking appropriate action when victims report a crime are among the most important duties of the police, and many residents of Washington have initiated contact with the police. Among our respondents, 40 percent of Blacks and 34 percent of Whites reported contacting police about a crime in the past year. Net of other factors in the model, these effects were quite salutary for 
African Americans: Black residents who initiated a crime-related encounter with police were more positive as a result. Whites, however, recorded no differences in their views that were linked to this experience.

By contrast, initiating contact with the police about some noncrime matter had no appreciable influence on confidence in the police. Overall, 45 percent of Blacks and 42 percent of Whites recalled calling the police for information, to report an accident, or for other routine matters in which the police might get involved. Perhaps because noncrime contacts are generally more mundane and less contentious than others, they had no effect on either group's assessments of officer misconduct.

Police-initiated contacts are quite another matter, however. Being involved in a police-initiated traffic stop had strong and uniform effects on members of both groups. Net of other factors in the model, Washingtonians who were stopped were more likely to report that officers were abusive toward residents of their neighborhood, and it did not matter whether they were driving and Black or driving and White. In fact, for Whites this was the second-most influential factor in the model. For African Americans, being pulled over had about the same influence as being under the age of 30 , having children living at home, and living in a neighborhood with social disorder problems. Police-initiated pedestrian stops, however, are consequential for Blacks only: Being stopped as pedestrians was strongly predictive of negative affect toward the police for Blacks but not for Whites.

It is also worth noting that the $R^{2}$ for Blacks is nearly twice as large as that for Whites. We attribute this to the larger context of racialized policing in America. For African Americans-much more so than for Whites-police misconduct is not an abstraction; on the contrary, it is an issue that resonates powerfully because of African Americans' long history of conflict with the police. The greater explanatory power of the model may reflect the special salience of the predictors for Black citizens. At the same time, Blacks were more divided than Whites over policing. The variance in the dependent variable for Whites (.12) was less than half that among Blacks (.29).

The findings support most of our hypotheses. The view that crime is a serious neighborhood problem was linked to perceptions of more serious police misconduct among Whites and Blacks (Hypothesis 1), and the same was true for perceived neighborhood disorder (Hypothesis 2). Assessments of effective community policing were associated with lower levels of perceived police wrongdoing, especially among Blacks (Hypothesis 3). According to Hypothesis 4, police-initiated contacts of all types exacerbate citizens' unfavorable views of the police, regardless of citizens' race. With the exception of police-initiated pedestrian stops of Whites (which are 
extremely infrequent), this hypothesis was supported. Hypothesis 5 predicted that citizen-initiated encounters would not affect perceptions of police misconduct for either Whites or Blacks. We found that race and the type of contact did make a difference. For Blacks but not Whites, crime-related contact ameliorated perceptions of police misconduct. Yet, routine noncrime contacts were unrelated to views of police misconduct for either group.

\section{Conclusion}

Our findings document the continued division among Blacks and Whites over policing. Net of other factors, African Americans were more likely than Whites to perceive police misconduct in Washington. But there is much more to the story than race differences alone. First, class matters. As indicated earlier, the literature is inconclusive regarding the effects of social class on citizens' perceptions of the police. Here we found that class shaped views of police misconduct among Whites and Blacks, with less-educated respondents more likely than their better-educated counterparts to believe that police misconduct is a problem in their local areas. This finding is consistent with that of another Washington study, which found that residents of a low-income Black neighborhood were between 4 and 7 times more likely than residents of a middle-class Black community to say that the police had stopped people on the street unjustifiably, verbally abused residents, or used excessive force against them (Weitzer 1999). The present study corroborates these results for the city as a whole. In Washington, DC, the lower one's social class position, the greater the perception that police wrongdoing is a problem in one's neighborhood-and this applies to Blacks and Whites alike.

A great deal of research has focused on demographic correlates of citizens' attitudes toward the police. The limits of this research are apparent once additional factors are incorporated into the analysis. At the experiential level, a growing body of recent studies (e.g., Skogan 2005, 2006a; Tyler and Huo 2002; Weitzer and Tuch 2006) highlight the importance of personal interactions with police officers in shaping larger attitudes toward the police. Similarly - and this is our second major conclusion-we find that views of the police are strongly influenced by experiential and situational factors. At the street level, police-citizen contacts play a mixed role. When officers stop residents in vehicles or on foot, people more frequently come away from the experience with the view that police misconduct is a 
problem in their locale. Traffic stops (which involved almost one fifth of adults in Washington) and pedestrian stops (which were much less frequent) increased perceptions of police misconduct, and pedestrian stops resonated particularly strongly among Blacks. Unlike street stops, however, professional handling of crime-related contacts seemed to enhance the image of the police among African Americans.

Third, among Blacks, living in neighborhoods that were reportedly rife with crime or disorder was associated with more negative views of the police. Among Whites, there was the same pattern for perceived neighborhood disorder but not for crime. The latter difference may have been due to the fact that there was less variance in perceptions among Whites of neighborhood crime problems (most of whom live in low-crime areas of the city), whereas Blacks reportedly live under more diverse neighborhood conditions. It is also possible that when crime is perceived as a big problem in predominantly Black neighborhoods, it is a higher order of seriousness than what Whites defined as big problems in their neighborhoods (Liska and Bellair 1995; Logan and Stults 1999). The link between neighborhood crime or disorder and residents' relations with the police is an important one, suggesting that enhanced police performance in crime control may help to reduce negative views of the police, which may in turn increase residents' willingness to report crimes and cooperate with police investigations.

Fourth, we hypothesized that the existence of community policing, as perceived by residents, would dilute the perception that police misconduct is a problem in one's neighborhood. Advocates of community policing have long claimed that it has the potential to yield dividends in reducing crime by addressing criminogenic neighborhood conditions and that it will also improve police-community relations. As indicated earlier, the literature finds mixed support for these predictions, but our findings lend credence to the proposition that community policing (or at least the two types examined here) can help improve residents' relations with the police. Community policing decreases the chances that citizens will view police misconduct as a problem in their neighborhood, and this was especially true for African Americans. It is important to note that the finding pertains to residents' perceptions of community policing in their neighborhoods, rather than actual police practices; but again, perceptions of reality matter greatly in shaping residents' confidence in the police, as the literature reviewed earlier indicates (e.g., Huebner et al. 2004).

A caveat should be made here: Important recent research concludes that the effects of demographic characteristics are reduced once neighborhood 
characteristics are factored into the equation (Reisig and Parks 2000; Sampson and Bartusch 1998; Schafer et al. 2003). Although we could not measure contextual factors directly and so relied instead on residents' perceptions of ecological conditions (which, again, can be as consequential as objective conditions), our findings are consistent with the literature that includes objective conditions. Like these studies, our work cautions against focusing on just one dimension (demographic, experiential, contextual) and instead lends support to a framework in which police-citizen relations are conditioned by a combination of factors.

This caveat points to one limitation of the present study. Another is that, as in all single-city case studies, the findings should not be generalized to other locales. As such, it is important to consider the possible impact of certain characteristics of Washington and comparable cities. Most of the literature over the past four decades has been confined to research on cities with majority-White police departments. This raises the intriguing question of whether police-citizen relations differ appreciably in cities with majorityBlack or majority-Hispanic police departments. Data drawn from a single city cannot address this question directly, but they can be provisionally compared to some other cities, as a prelude to more systematic comparative analyses in the future.

Although Blacks in Washington were more critical of the police than Whites, it is noteworthy that only a minority of Black residents (26 percent to 29 percent) perceived any of the types of police misconduct to be a problem in their neighborhood. Fortuitously, a survey taken at the same time, using identical questions, found that Chicago's Black population was much more critical of the police than were their counterparts in Washingtonwith half of Chicago's Blacks seeing each of the three types of misconduct (and police corruption as well) as a problem in their neighborhoods (Skogan and Hartnett 1998). ${ }^{13}$ Chicago and Washington differ in composition. Washington is a majority-Black city with a majority-Black police department (66 percent Black in 1997), whereas Chicago has a majorityWhite police department (63 percent White in 1997) and the city has relatively equal numbers of Blacks, Whites, and Hispanics.

The disparate racial composition of the two cities' police departments may account, at least in part, for differences in police-community relations. It has been hypothesized that a police department's racial composition influences citizens' confidence in the police (Frank et al. 1996). ${ }^{14}$ Our Washington findings lend support to this hypothesis, but research on a few 
other majority-Black cities with majority-Black police departments suggests that the racial composition thesis requires further testing. In Detroit, Michigan, Blacks and Whites were found to be "massively dissatisfied" with the police (Welch et al. 2001:147). And another study of Detroit and New Orleans, Louisiana, found that the majority-Black character of the cities and their police departments did not improve Black residents' views of the police, although it appeared to diminish Whites' confidence in the police (Howell et al. 2004). These results suggest that police diversification does not necessarily live up to expectations - perhaps because police practices have not sufficiently improved, because officers of all races tend to behave similarly (Riksheim and Chermak 1993) or because other factors trump racial composition.

However, the dependent variables in the Washington and Chicago studies and those in Detroit and New Orleans differ substantially. Welch et al. (2001) questioned Detroit residents on their overall satisfaction with police, how satisfied they were with police protection in their neighborhoods, whether officers respond equally quickly to calls from Blacks and Whites, and whether police discriminate against Blacks in stops and searches-with only the last item being roughly comparable to an item in the Washington and Chicago studies. Similarly, Howell and colleagues study (2004) of New Orleans and Detroit combined five items into a scale (police courtesy, response time, effectiveness in apprehending suspects, excessive force, and overall quality of police protection), only one of which (excessive force) is comparable to a question in the Washington and Chicago surveys. In addition, Howell et al. sampled registered voters, whereas the Washington and Chicago samples were drawn from the larger population. These differences complicate comparisons among the three cities.

The advantage of the Chicago study is its use of questions identical to those used in Washington, which facilitates direct comparisons between the two. That residents of Washington are considerably more confident than their counterparts in Chicago in the belief that city police officers are not involved in misconduct may have something to do with racial composition, but at this stage, we must regard this as an intriguing hypothesis in need of further, systematic investigation. The contribution of the present study is the light that it sheds on police-citizen relations in a type of urban context that has rarely been examined-a minority-White city-a context that is becoming increasingly common throughout the United States. 


\section{Appendix: Means (and Standard Deviations) of Study Variables}

\begin{tabular}{|c|c|c|c|}
\hline $\begin{array}{l}\text { Variable } \\
\text { Variable }\end{array}$ & $\begin{array}{c}\text { Total } \\
\text { Sample } \\
(N=2,731)\end{array}$ & $\begin{array}{l}\text { Whites } \\
(n=915)\end{array}$ & $\begin{array}{c}\text { Blacks } \\
(n=1,816)\end{array}$ \\
\hline Race $(1=$ Black $)$ & $0.66(0.47)$ & - & - \\
\hline Education & $13.55(2.79)$ & $15.36(2.02)$ & $12.63(2.67)$ \\
\hline Gender $(1=$ male $)$ & $0.46(0.50)$ & $0.56(0.50)$ & $0.41(0.49)$ \\
\hline Children living at home $(1=$ yes $)$ & $0.32(0.47)$ & $0.14(0.35)$ & $0.41(0.49)$ \\
\hline Married (1 = yes) & $0.29(0.45)$ & $0.33(0.47)$ & $0.27(0.44)$ \\
\hline Age $18-29$ ( $1=$ yes $)$ & $0.23(0.42)$ & $0.28(0.45)$ & $0.21(0.40)$ \\
\hline Age $30-59(1=$ yes $)$ & $0.58(0.49)$ & $0.57(0.50)$ & $0.58(0.49)$ \\
\hline Age $60+(1=$ yes $)$ & $0.19(0.39)$ & $0.15(0.35)$ & $0.21(0.41)$ \\
\hline Perceived neighborhood crime ${ }^{a}$ & $1.63(0.53)$ & $1.61(0.47)$ & $1.64(0.56)$ \\
\hline Perceived neighborhood disorder ${ }^{a}$ & $1.66(0.52)$ & $1.59(0.46)$ & $1.69(0.55)$ \\
\hline Perceived community policing ${ }^{a}$ & $2.97(0.77)$ & $3.02(0.69)$ & $2.94(0.81)$ \\
\hline Citizen-initiated crime contact (count) & $0.64(0.99)$ & $0.55(0.92)$ & $0.69(1.03)$ \\
\hline Citizen-initiated noncrime contact (count) & $0.81(1.15)$ & $0.73(1.05)$ & $0.85(1.20)$ \\
\hline Police-initiated vehicle contact $(1=$ yes $)$ & $0.19(0.39)$ & $0.17(0.38)$ & $0.20(0.40)$ \\
\hline Police-initiated pedestrian contact $(1=$ yes $)$ & $0.05(0.22)$ & $0.02(0.13)$ & $0.07(0.25)$ \\
\hline Perceptions of police misconduct & $1.29(0.50)$ & $1.15(0.35)$ & $1.36(0.54)$ \\
\hline
\end{tabular}

a. Standardized for analysis, based on the total sample.

\section{Notes}

1. According to the 2000 U.S. Census, 99.2 percent of home owners in Washington, DC, had telephone service, compared to 96.3 percent of renters. The nationwide figures are 98.8 and 95.1, respectively (see U.S. Census Bureau, 2008).

2. We compared several demographic factors-education, marital status, number of children living at home, age, and gender - before and after eliminating cases with missing data on the other predictors. Attrition had no appreciable impact on the demographic composition of the sample.

3. We recognize that verbal and physical abuse differ in seriousness, but the survey instrument combined them. The item "being too tough" on people who are stopped is somewhat vague, but it implies a kind of harsh or aggressive treatment and may thus overlap with the item measuring verbal and physical abuse, although the latter is not restricted to the context of a stop.

4. As is typical in surveys, there was a fair amount of missing data in responses to each question. At the low end, 14 percent of respondents did not have an opinion about unwarranted stops, and at the high end, 18 percent had no opinion about verbal or physical abuse. Nonresponse was generally more common among respondents who had little experience with the police. This included older and retired people, those who did not have any children living at home, and respondents who reported that they had not contacted the police nor been stopped by them in the past year. 
5. Although prior research has found that objective measures of neighborhood conditions shape citizens' attitudes toward the police over and above the influence of perceptual factors (for a discussion, see Weitzer and Tuch 2006), the amount of variance typically explained by the former, as well as the magnitude of their effects, is not substantial (Liska 1990). Thus, the lack of measures for objective neighborhood conditions should not significantly bias our results.

6. A factor analysis of these 11 items revealed a two-factor solution, thereby justifying their separate measurement. Moreover, treating perceptions of neighborhood crime and disorder as being conceptually distinct is consistent with the majority of previous research.

7. Because we have no data on the race of officers involved in these citizen contacts, we do not assume a priori that our respondents' contacts were with Black officers. But because two thirds of officers in Washington are Black, there is a high likelihood that many of the encounters involved Black officers. Other research indicates that citizens vary considerably in their perceptions and reported experiences with officers of different racial backgrounds, with some people holding positive views of Black and Hispanic officers and with others viewing them as being no different than White officers (Weitzer and Tuch 2006).

8. Of course, stops are not necessarily unwarranted (i.e., an instance of police misconduct), but the greater the number of stops, the greater the possibility of unwarranted stops and the greater the opportunity for other types of police misconduct (verbal abuse, excessive force, etc.).

9. It is possible that an even larger percentage of the Black population in Washingtonyoung Black males in particular-would be stopped if the police department was majority White, but it is noteworthy that the figures on Chicago (whose police department was 63 percent White in 1997) are similar to Washington's. In Washington, 61 percent of 18- to 29-yearold Black males reported being stopped in the past year, compared to 64 percent of 18- to 25-year-old Black males in Chicago (Skogan 2005).

10. The use of ordinal measures as dependent variables in ordinary least squares models is common in social science research because the error distributions of ordinal variables tend toward normality in large probability samples, such as those used here (see Neter et al. 2004), especially when the number of dependent variable categories exceeds five (Achen 1982).

11. See the appendix for descriptive statistics on all study variables.

12. Perceptions of neighborhood crime and disorder, though highly intercorrelated $(r=.66)$, are not collinear. Moreover, tolerance tests on the regression coefficients in the model show no problems with collinearity.

13. The two cities are similar, however, in Whites' perceptions of police misconduct (few Whites consider it a problem) and in Blacks' reports of being stopped by a police officer in the past year.

14. Frank et al. (1996) found support for this proposition in a Detroit study, but their study was limited to four neighborhoods in the city.

\section{References}

Achen, Christopher. 1982. Interpreting and Using Regression. Thousand Oaks, CA: Sage. Alpert, Geoffrey and Roger Dunham. 1988. Policing Multi-Ethnic Neighborhoods. New York: Greenwood.

Baumeister, Roy, Ellen Bratslavsky, Catrin Finkenauer, and Kathleen Vohs. 2001. "Bad Is

Stronger Than Good." Review of General Psychology 5:323-70. 
Bayley, David and Harold Mendelsohn. 1969. Minorities and the Police. New York: Free Press.

Blumer, Herbert. 1958. "Race Prejudice as a Sense of Group Position." Pacific Sociological Review 1:3-7.

Brown, Ben and William Benedict. 2002. "Perceptions of the Police." Policing 25:543-80.

Brunson, Rod and Jody Miller. 2006. "Young Black Men and Urban Policing in the United States." British Journal of Criminology 46:613-40.

Bureau of Justice Statistics. 1999. Criminal Victimization and Perceptions of Community Safety in 12 Cities, 1998. Washington, DC: U.S. Department of Justice.

- 2004. Law Enforcement Management and Administrative Statistics, 2000. Washington, DC: U.S. Department of Justice.

Cao, Liqun, James Frank, and Francis Cullen. 1996. "Race, Community Context, and Confidence in the Police." American Journal of Police 15:3-21.

Cheurprakobkit, Sutham. 2000. "Police-Citizen Contact and Police Performance." Journal of Criminal Justice 28:325-36.

Dean, Deby. 1980. "Citizens' Ratings of the Police: The Difference Contact Makes." Law and Policy Quarterly 2:445-71.

Decker, Scott. 1981. "Citizen Attitudes toward the Police: A Review of Past Findings and Suggestions for Future Policy." Journal of Police Science and Administration 9:80-87.

Decker, Scott and Russell Smith. 1980. "Police Minority Recruitment." Journal of Criminal Justice 8:387-93.

Engel, Robin. 2005. "Citizens' Perceptions of Distributive and Procedural Injustice during Traffic Stops with Police." Journal of Research in Crime and Delinquency 42:445-81.

Fagan, Jeffrey and Garth Davies. 2000. "Street Stops and Broken Windows: Terry, Race, and Disorder in New York City." Fordham Urban Law Journal 28:457-49.

Frank, James, Steven Brandl, Francis Cullen, and Amy Stichman. 1996. "Reassessing the Impact of Race on Citizen's Attitudes toward the Police." Justice Quarterly 13:321-34.

Grinc, Randolph. 1994. "Angels in Marble: Problems in Stimulating Community Involvement in Community Policing." Crime and Delinquency 40:437-68.

Hagan, John and Celesta Albonetti. 1982. "Race, Class, and the Perception of Criminal Injustice in America." American Journal of Sociology 88:329-55.

Hahn, Harlan. 1971. "Ghetto Assessments of Police Protection and Authority." Law and Society Review 6:183-94.

Howell, Susan, Huey Perry, and Matthew Vile. 2004. "Black Cities, White Cities: Evaluating the Police." Political Behavior 26:45-68.

Huebner, Beth, Joseph Schafer, and Timothy Bynum. 2004. "African American and White Perceptions of Police Services." Journal of Criminal Justice 32:123-35.

Human Rights Watch. 1998. Shielded from Justice: Police Brutality and Accountability in the United States. New York: Human Rights Watch.

Hurst, Yolander, James Frank, and Sandra Browning. 2000. "The Attitudes of Juveniles toward the Police." Policing 23:37-53.

Jacob, Herbert. 1971. "Black and White Perceptions of Justice in the City." Law and Society Review 6:69-90.

Jacobs, David and Robert O’Brien. 1998 “The Determinants of Deadly Force. A Structural Analysis of Police Violence." American Journal of Sociology 103:837-62.

Jesilow, Paul, J'ona Meyer, and Nazi Namazzi. 1995. "Public Attitudes toward the Police." American Journal of Police 14:67-88.

Kane, Robert. 2002. "The Social Ecology of Police Misconduct." Criminology 40:867-96. 
Kappeler, Victor, Richard Sluder, and Geoffrey Alpert. 1998. Forces of Deviance: Understanding the Dark Side of Policing. Prospect Heights, IL: Waveland.

Klinger, David. 1997. "Negotiating Order in Police Work: An Ecological Theory of Police Response to Deviance." Criminology 35:277-306.

Kubrin, Charis and Ronald Weitzer. 2003. "New Directions in Social Disorganization Theory." Journal of Research in Crime and Delinquency 40:374-402.

Leiber, Michael, Mahesh Nalla, and Margaret Farnworth. 1998. "Explaining Juveniles' Attitudes toward the Police." Justice Quarterly 15:151-73.

Liska, Allen. 1990. "The Significance of Aggregate Dependent Variables and Contextual Independent Variables for Linking Macro and Micro Theories." Social Psychology Quarterly 53:292-301.

Liska, Allen and Paul Bellair. 1995. "Violent-Crime Rates and Racial Composition." American Journal of Sociology 101:578-610.

Logan, John and Brian Stults. 1999. "Racial Differences in Exposure to Crime." Criminology 37:251-76.

MacDonald, John, Robert Stokes, Greg Ridgeway, and K. Jack Riley. 2007. "Race, Neighborhood Context, and Perceptions of Injustice by the Police in Cincinnati." Urban Studies 13:2567-85.

Mastrofski, Stephen, Michael Reisig, and John McCluskey. 2002. "Police Disrespect toward the Public." Criminology 40:519-51.

Mollen Commission. 1994. Report of the Commission to Investigate Allegations of Police Corruption. New York: Mollen Commission.

Murty, Komanduri, Julian Roebuck, and Joann Smith. 1990. "The Image of the Police in Black Atlanta Communities." Journal of Police Science and Administration 17:250-57.

Neter, John, Michael Kutner, Christopher Nachtsheim, and William Wasserman. 2004. Applied Linear Statistical Models, 4th ed. Boston: McGraw-Hill.

RAND. 2005. Police-Community Relations in Cincinnati. Santa Monica, CA: RAND.

Reisig, Michael and Roger Parks. 2000. "Experience, Quality of Life, and Neighborhood Context." Justice Quarterly 17:607-629.

—. 2004. "Can Community Policing Help the Truly Disadvantaged?" Crime and Delinquency 50:139-67.

Riksheim, Eric and Steven Chermak. 1993. "Causes of Police Behavior Reconsidered." Journal of Criminal Justice 21:353-82.

Rosin, Paul and Edward Royzman. 2001. "Negativity Bias, Negativity Dominance, and Cognition." Personality and Social Psychology Review 5:296-320.

Sampson, Robert and Dawn Bartusch. 1998. "Legal Cynicism and Subcultural Tolerance of Deviance." Law and Society Review 32:777-804.

Sampson, Robert and Stephen Raudenbush. 1999. "Systematic Social Observation of Public Spaces: A New Look at Disorder in Urban Neighborhoods." American Journal of Sociology 105:603-51.

Scaglion, Richard and Richard Condon. 1980. "Determinants of Attitudes toward City Police." Criminology 17:485-94.

Schafer, Joseph, Beth Huebner, and Timothy Bynum. 2003. "Citizen Perceptions of Police Services: Race, Neighborhood Context, and Community Policing." Police Quarterly 6:440-68.

Sherman, Lawrence. 1983. "After the Riots: Police and Minorities in the United States." Pp. 212-35 in Ethnic Pluralism and Public Policy, edited by Nathan Glazer and K. Young. Toronto, ON: Lexington. 
Skogan, Wesley. 1979. "Citizen Satisfaction with Police Services." Pp. 29-42 in Evaluating Alternative Law Enforcement Policies, edited by Ralph Baker and Fred Meyer. Lexington, MA: Lexington Books.

- 1990. Disorder and Decline: Crime and the Spiral of Decay in American Neighborhoods. Berkeley, CA: University of California Press.

. 2005. "Citizen Satisfaction with Police Encounters." Police Quarterly 8:298-321.

. 2006a. "Asymmetry in the Impact of Encounters with Police." Policing and Society 16:99-126.

- 2006b. Police and Community in Chicago: A Tale of Three Cities. New York: Oxford University Press.

Skogan, Wesley and Susan Hartnett. 1998. "A Comparison of Chicago and District of Columbia Surveys." Unpublished report, Northwestern University, Chicago, IL.

Smith, Douglas. 1986. "The Neighborhood Context of Police Behavior." Pp. 313-41 in Crime and Justice, edited by Albert Reiss and Michael Tonry. Chicago: University of Chicago Press.

Smith, Douglas, Nanette Graham, and Bonney Adams. 1991. "Minorities and the Police." Pp. 22-35 in Race and Criminal Justice, edited by Michael Lynch and E. Britt Patterson. New York: Harrow and Heaton.

Stone, Vanessa and Nick Pettigrew. 2000. The Views of the Public on Stops and Searches. London: Home Office.

Sykes, Richard and John Clark. 1975. "A Theory of Deference Exchange in Police-Civilian Encounters." American Journal of Sociology 81:584-600.

Terrill, William and Michael Reisig. 2003. "Neighborhood Context and Police Use of Force." Journal of Research in Crime and Delinquency 40:291-321.

U.S. Census Bureau. 2008. QT-H9: Occupancy, Telephone Service, Housing Facilities, and Meals Included in Rent. Washington, DC: U.S. Census Bureau.

Tyler, Tom and Yuen Huo. 2002. Trust in the Law. New York: Russell Sage.

Walker, Samuel and K. B. Turner. 1992. A Decade of Modest Progress: Employment of Black and Hispanic Police Officers, 1983-1992. Omaha: University of Nebraska.

Washington Post. 1998. "District Police Lead Nation in Shootings." November 15: A1, A25-A27.

- 2000. "Shootings by DC Police Decline 66 percent in 1999.” January 1, B1, B7.

2001. "Deadly Force Plummets in DC." January 31, A1, A11.

Weitzer, Ronald. 1999. "Citizens' Perceptions of Police Misconduct: Race and Neighborhood Context." Justice Quarterly 16:819-46.

— 2000a. "Racialized Policing: Residents' Perceptions in Three Neighborhoods." Law and Society Review 34:129-55.

- 2000b. "White, Black, or Blue Cops? Race and Citizen Assessments of Police Officers." Journal of Criminal Justice 28:313-24.

- 2002. "Incidents of Police Misconduct and Public Opinion." Journal of Criminal Justice 30:397-408.

2005. "Can the Police Be Reformed?" Contexts 4:21-26.

Weitzer, Ronald and Steven Tuch. 1999. "Race, Class, and Perceptions of Discrimination by the Police." Crime and Delinquency 45:494-507.

- 2002. "Perceptions of Racial Profiling: Race, Class, and Personal Experience." Criminology 40:435-56.

- 2006. Race and Policing in America: Conflict and Reform. New York: Cambridge University Press. 
Welch, Susan, Lee Sigelman, Timothy Bledsoe, and Michael Coombs. 2001. Race and Place: Race Relations in an American City. New York: Cambridge University Press.

Williams, Brian. 1996. Citizen Perspectives on Community Policing. Albany, NY: State University of New York Press.

Wortley, Scot, John Hagan, and Ross Macmillan. 1997. "Just Desserts? The Racial Polarization of Perceptions of Criminal Injustice." Law and Society Review 31:637-76.

Xu, Yili, Mora Fiedler, and Karl Flaming. 2005. "Discovering the Impact of Community Policing: The Broken Windows Thesis, Collective Efficacy, and Citizens' Judgment." Journal of Research in Crime and Delinquency 42:147-86.

Ronald Weitzer is a professor of sociology at George Washington University. He has conducted research on police-minority relations in South Africa, Northern Ireland, Israel, and the United States. His books include Policing under Fire: Ethnic Conflict and Police-Community Relations in Northern Ireland and Race and Policing in America (with Steven Tuch). He is also an expert on the sex industry and currently researching legal prostitution systems.

Steven A. Tuch is a professor of sociology, public policy, and public administration at George Washington University. His research focuses on racial inequality, public opinion, and social change in the post-Communist nations of Central and Eastern Europe. He is coauthor (with Ronald Weitzer) of Race and Policing in America, coeditor (with Yoku Shaw-Taylor) of The Other African Americans: Contemporary African and Caribbean Immigrants in the United States, and coeditor (with Jack K. Martin) of Racial Attitudes in the 1990s.

Wesley G. Skogan holds a joint appointment with Northwestern University's Institute for Policy Research and political science department. His research focuses on the interface between the public and the criminal justice system. He heads a team evaluating the implementation and impact of Chicago's community policing program, and his book Police and Community in Chicago: A Tale of Three Cities reports the findings of a 13-year study. He is the author of two reports published by the British Home Office-The Public and the Police in England and Wales (1990) and Contacts between Police and the Public (1994)—which examine citizen contact and satisfaction with policing in Britain. From 1999 to 2003, he chaired the National Research Council's Committee on Research on Police Policies and Practices, and he was a member of the council's Committee on Law and Justice. 